Pesq. Vet. Bras. 38(5):883-888, maio 2018

\title{
Genetic engineering of Theileria parva lactate dehydrogenase gene: a new anti-theilerial target ${ }^{1}$
}

\author{
Irmak Icen-Taskin²*, Omer Munzuroglu ${ }^{3}$ and Hikmet Geckil ${ }^{4}$
}

\begin{abstract}
Icen-Taskin I., Munzuroglu O. \& Geckil H. 2018. Genetic engineering of Theileria parva lactate dehydrogenase gene: a new anti-theilerial target. Pesquisa Veterinária Brasileira 38(5):883-888. Department of Biology, Firat University, 23119 Elazig, Turkey. E-mail: irmak.icen@hotmail.com

Theileria parva is the causative agent of East Coast Fever (ECF), a tick borne disease, which results in major economic losses in cattle. Major problems in dealing with this illness are the high cost of drugs, development of resistance, and absence of effective vaccines. Thus, exploiting new targets for cost effective and higher therapeutic value drugs are imperative. Glycolysis is the main pathway for generation of ATP in T. parva, given its development inside erythrocytes. Thus, the enzymes of this pathway may prove potential targets for designing new-generation anti-theilerials. Lactate dehydrogenase of T. parva (TpLDH) has the highest activity of all glycolytic enzymes and thus we selected this enzyme as the potential therapeutic target. Our study is the first to report the isolation, removal of introns through directed mutagenesis, and cloning of $T p \mathrm{LDH}$ and showing that amino acid insertions or deletions most notably corresponded to a 5-amino acid sequence (Asn-91A, Glu-91B, Glu-91C, Trp-91D, Asn-91E) between Ser-91 ve Arg-92 of the enzyme. This region is also present in other apicomplexan such as Babesia bovis, a pathogen of cattle and Plasmodium falciparum, a human pathogen. Providing as the attachment site for the enzyme inhibitors and not being present in LDH of respective hosts, we propose this site as an attractive drug target. The work here is expected to lead new studies on detailed structural and kinetic aspects of apicomplexan LDHs and development of new inhibitors.
\end{abstract}

INDEX TERMS: Theileria parva, lactate dehydrogenase, anti-theilerial, East coast fever, parasite.

\section{INTRODUCTION}

Theileria spp. are tick borne protozoan parasites that are members of the phylum Apicomplexa which includes many species of both medical (e.g., Plasmodium spp.; Toxoplasma) and veterinary (e.g. Babesia, Eimeria, Theileria) importance (Shaw 1997). T. parva is one of the two economically important species of the Theileria genus transmitted by Rhipicephalus ticks (Yamada et al. 2008) and causes an often fatal lympho-proliferative disease of cattle (Morrison 2009) known as East Coast Fever (ECF). The disease caused by the parasite affects a large proportion of domestic and wild animals. The parasite is highly pathogenic for cattle, leading to serious economic losses (Mukhebi et al. 1992).

\footnotetext{
${ }^{1}$ Received on April 14, 2017.

Accepted for publication on May 8, 2017.

${ }^{2}$ Department of Biology, Firat University, 23119 Elazig, Turkey. *Corresponding author: irmak.icen@hotmail.com

${ }^{3}$ Department of Bioengineering, Firat University, 23119 Elazig, Turkey.

${ }^{4}$ Department of Molecular Biology and Genetics, Inonu University, 44280 Malatya, Turkey.
}

As the disease is tick-borne, it is hypothesized that breaking any of the links between the chain of host and pathogen would help prevent ECF. An important problem is the high cost of the acaricides used for tick control (Walker 2007) and the rapid resistance development (Benavides et al. 2000, Miller et al. 2002). Moreover, to date, there is no safe and effective vaccine against Theileria spp. (Elisa et al. 2015, Osman \& Al-Gaabary 2007, Walker 2007). Buparvaquone, an antiprotozoal drug, is widely shown to be an effective antitheilerial (Dolan et al. 1992, McHardy et al. 1985). Although antitheilerials are used in the treatment of the disease (Dolan et al. 1992, McHardy et al. 1985), their efficacy is limited (Singh et al. 1993). Also, development of resistance to antitheilerials is a major problem (Marsolier et al. 2015, Mhadhbi et al. 2010, 2015, Sharifiyazdi et al. 2012). Thus, there is an urgent need for a safe, effective, and inexpensive antitheilerial.

Potential weak points of the energy metabolism may provide a chemotherapeutic target for the design of a new antitheilerial. However, almost the impossibility of removing all T. parva schizonts without any contamination by host 
materials (Hung \& Parkinson 2011), cost, and length of isolation have delayed the studies on the enzymes of energy metabolism in schizonts (Kiama et al. 1999). On the other hand, previous studies showed that glycolytic enzymes had high activity in T. parva schizonts and this being highest for the lactate dehydrogenase (Kiama et al. 1999). This is the type of energetic metabolism utilizing glycolysis as the main route for energy production (Kiama et al. 1999) is similar to that of Plasmodium in the erythrocytic stage (Sherman 1979). Given this, LDH enzyme of the Theileria parva was selected as the target for structure-based drug design studies, as was the case for others apicomplexan (Cameron et al. 2004, Nural et al. 2016).

Building on the present day knowledge of structural differences between the host and the parasite LDH, we have isolated and cloned Theileria parva lactate dehydrogenase $(T p L D H)$ gene to study its potential as the new target for the development of selective inhibitors.

\section{MATERIALS AND METHODS}

Bacterial cloning and growth. Unless otherwise stated, all general methods were followed according to well-established standard protocols (Sambrook \& Russell 2006). Genomic DNA including TpLDH gene was obtained from ILRI (International Livestock Research Institute, Nairobi, Kenya). The host bacterial strain was Escherichia coli JM103 (endA1 glnV44 sbcBC rpsL thi-1 $\Delta$ (lac-proAB) $\mathrm{F}^{\prime}$ [traD36 proAB ${ }^{+}$lacl ${ }^{\mathrm{q}}$ lacZ $\left.\triangle \mathrm{M} 15\right)$. TpLDH gene was cloned using the pGEM-T easy vector sytem I (Promega, USA). Growth medium was Luria-Bertani Broth (LB). When required, $0.1 \%(\mathrm{v} / \mathrm{v}$ ) of a filter sterilized solution of $100 \mathrm{mg} / \mathrm{ml}^{-1}$ ampicillin was added after autoclaving the medium. The selection of presumptive transformants was done on LB-agar plates containing $20 \mathrm{mg} / \mathrm{ml}$ IPTG, $20 \mathrm{mg} / \mathrm{ml}$ $\mathrm{X}$-Gal and $100 \mu \mathrm{g} / \mathrm{ml}$ ampicillin.

Amplification of $T p \mathbf{L D H}$. The initial sequence of $T p \mathrm{LDH}$ gene was retrieved from NCBI with the accession number of XM_761610.1. The sequence was utilized to design two particular oligonucleotide primers for the amplification of the LDH gene from genomic DNA of T. parva. The forward primer was TpLDHF and reverse primer was TpLDHR:

\section{5'-ATGTCTGGAATTAGGAGGAAGTTGATTAG-3' \\ 5'-TTATTTGATGAGTGATTCTAGTCGTCTG-3'}

The PCR was performed as follow; the mixture of PCR contained $5 \mu$ l of Taq DNA Polymerase buffer (10X), $3 \mu \mathrm{l} \mathrm{MgCl}_{2}(25 \mathrm{mM}), 5 \mu \mathrm{l}$ of a stock of dNTPs ( $2 \mathrm{mM}), 2.5 \mu$ l forward oligonucleotide primer (20pmol), $2.5 \mu \mathrm{l}$ reverse oligonucleotide primer $(20 \mathrm{pmol}), 0.5 \mu \mathrm{l}$ T.parva genomic DNA (50ng), 0.5 $\mathrm{l}$ Taq DNA Polymerase ( 5 units), and $\mathrm{H}_{2} \mathrm{O}$ to a final volume of $50 \mu \mathrm{l}$. A full thermal cycle was adjusted to $94^{\circ} \mathrm{C}$ for $1.5 \mathrm{~min}$ for DNA denaturation, $55^{\circ} \mathrm{C}$ for $2 \mathrm{~min}$ for annealing, and $72^{\circ} \mathrm{C}$ for $2 \mathrm{~min}$ for the extension for a total of 30 cycles. The confirmation of the amplified DNA was done on a 1\% agarose gel from which DNA band was extracted using QIA Quick Gel Extraction Kit (QIAGEN).

Ligation and transformation. Gel purified PCR products were inserted into pGEM-T easy vector system (Promega) and cloned into E. coli JM103 using standard cloning protocols. This vector contains multiple cloning sites (MCS) containing a range of restriction enzyme recognition sites, the lacZ gene for blue white selection and an ampicillin resistance gene for antibiotic selection. The mixture for ligation of PCR products to $\mathrm{pGEM-T} \mathrm{easy} \mathrm{subcloning} \mathrm{vector} \mathrm{contained}$ $5 \mu \mathrm{l} 2 \mathrm{X}$ ligase buffer, $1 \mu \mathrm{l}$ pGEM-T easy vector, 100ng DNA (insert), $1 \mu \mathrm{l} 44$ ligase and sterile $\mathrm{dH} 2 \mathrm{O}$ to complete the volume to $10 \mu \mathrm{l}$. Ligation was carried out at $4^{\circ} \mathrm{C}$ for $16 \mathrm{~h}$. The recombinant plasmid containing the TpLDH gene transformed to the competent bacterial cells prepared by the calcium chloride method.

Removing introns by site-directed mutagenesis. Site-directed mutagenesis was performed to remove two introns present in the TpLDH gene (Horton et al. 2013). Briefly, TpLDH gene was amplified as 3 ( $\mathrm{A}, \mathrm{B}$ and $\mathrm{C}$ ) gene fragments which were complementary to each other at the end:

TpLDHF 5'-ATGTCTGGAATTAGGAGGAAGTTGATTAG-3' and TpLDHEx1R 5'-CAGCGCCAATATTGGGGACAATATC-3',

TpLDHEx2F 5'- GATATTGTCCCCAATATTGGCGCTG-3' and TpLDHEx2R 5'- AGCCTTCGCCAAACCGGCGGTAAC-3',

TpLDHEx3F 5'- GTTACCGCCGGTTTGGCGAAGGCT-3 and TpLDHR 5''TTATTTGATGAGTGATTCTAGTCGTCTG-3'

Above primers were used to produce A, B and C fragments, respectively. Using Go taq DNA Polymerase, the fragments were amplified by PCR using the appropriate primer set with 30 cycles, each with denaturation, annealing and extension at $94^{\circ} \mathrm{C}$ for $1 \mathrm{~min}$, $55^{\circ} \mathrm{C}$ for $2 \mathrm{~min}$ and $72^{\circ} \mathrm{C}$ for $2 \mathrm{~min}$, respectively. The three overlapping fragments were then joined by overlap extension reaction.

DNA sequencing and bioinformatics tools for molecular modeling. Cloned TpLDH gene was firstly checked through colony PCR using the TpLDHF and TpLDHR primers to confirm the correct DNA locus. Then plasmid DNA was isolated using QIA Miniprep Kit (QIAGEN) according to the manufacturer instructions and sent to Iontek (Istanbul) for sequencing.

A range of Web-based tools were used for analysis of DNA and protein sequences. Lactate dehydrogenase sequences of apicomplexan parasites and the host B. taurus were obtained from National Centre for Biotechnology Information (NCBI). The primers were designed based on the NCBI reference sequence (NC_007344.1) for the provisional TpLDH from the whole genome sequence of T. parva. The LDH sequences of T.annulata (accession no: XM_948495) and B. taurus (accession no: NM_174099.2) were used for comparison. Both strands of $T p L D H$ were sequenced and the alignment results were compared using Lipper Centre for Computational Genetics of Harvard University. ClustalW2 tool was used to align the sequences at the nucleotide and amino acid level (Chenna et al. 2003). The positions of exons and introns were determined via the GSDS application (Guo et al. 2007). Homology modeling of BtLDH-A and TpLDH was conducted by using Phyre2 web (Kelley et al. 2015).

\section{RESULTS}

\section{Amplification, cloning and DNA sequencing of the Theileria parva LDH gene}

Amplification and cloning of a predicted 1353bp band from T. parva genomic DNA was successfully carried out by using TpLDHF and TpLDHR oligonucleotides. After extraction, the PCR products were analyzed on a $1 \%(\mathrm{w} / \mathrm{v})$ agarose gel electrophoresis (Fig.1), and bands with expected size (1353bp) were subcloned into $\mathrm{pGEM}^{\circledR}$ Teasy vector which was transformed into E.coli JM103. Sequences analysis showed that 1353 base pair length $T p \mathrm{LDH}$ gene contained 2 introns, 3 exons.

\section{Removing of introns from $T p L D H$ by using site-directed mutagenesis}

The sequences analysis indicated that $\mathrm{T} p \mathrm{LDH}$ gene is 1353 base pair in length and contains 3 open reading frames (ORF) of $121 \mathrm{bp}, 128 \mathrm{bp}$, and $717 \mathrm{bp}$, named as A, B, and C fragments respectively. The fragments were separated by two introns 


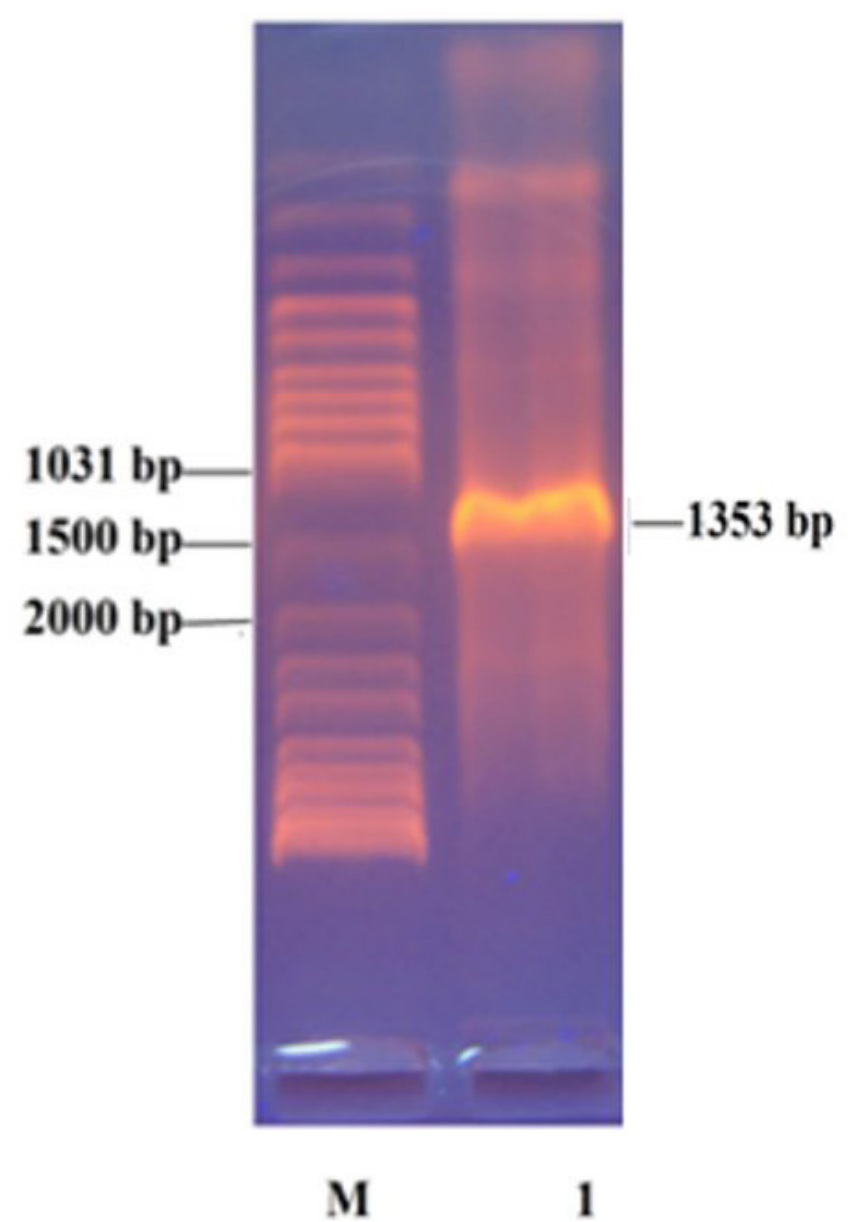

Fig.1. Agarose gel electrophoresis of PCR products amplified TpLDH gene from genomic DNA of Theileria parva. $\mathrm{M}=$ Marker, $1=T p \mathrm{LDH}$. which were removed by site-directed mutagenesis (Fig.2A). Three sets of oligonucleotides primers were used to resolve the overlapping exons. These results showed that site-directed mutagenesis can effectively be used to remove introns in the case of difficulty arising from obtaining cDNA. The fragments (i.e. A, B, C) were then combined with PCR amplification through their complementary end sequences, resulting the full length 966bp coding gene starting with ATG and ending with TAA (stop) codon (Fig.2B).

\section{Multiple amino acid sequence alignment}

Isolated and cloned nucleotide sequence of TpLDH gene was aligned and compared both with Theileria annulata lactate dehydrogenase (TaLDH) and the host Bos taurus lactate dehydrogenase (BtLDH) genes. Results showed that the mutations on TpLDH corresponded to the same position on BtLDH which manifested themselves in similar amino acid insertions or deletions on the LDH enzyme. Most notable difference between $T p L D H$ and $B t L D H$ was a penta peptide (Asn-91A, Glu-91B, Glu-91C, Trp-91D, Asn-91E) insertion on $T p L D H$ between positions serine 91 and arginine 92, making the active site loop of the enzyme. This five amino acid insertion is also present in TaLDH sequences (Fig.3).

\section{Homology modeling of Theileria parva and Bos taurus LDHs}

The amino acid sequence acquired after the exclude of the two introns from the gene utilized to demonstrate the 3D structure of TpLDH by Phyre2 web portal (Fig.4A). BtLDH amino acid sequence (AAI46211.1) data from GenBank was also used for comparison (Fig.4B). The substrate specificity loop (residues 92-96) has a five residue insert which is absent in BtLDHs (Fig.4C).

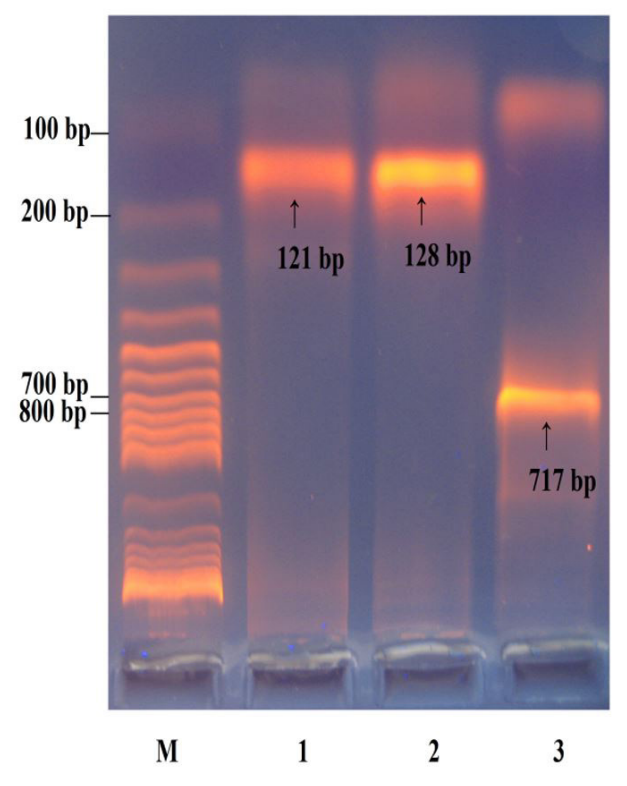

(A)

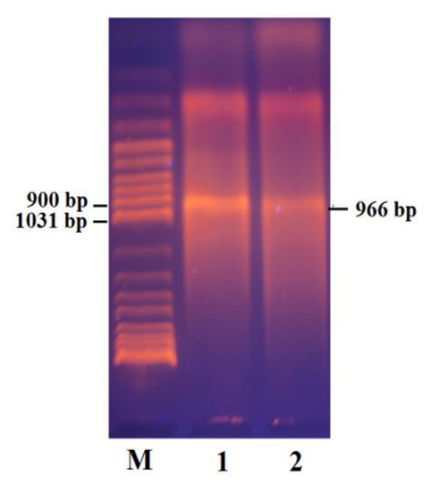

(B)

Fig.2. Agarose gel electrophoresis of PCR products amplified to produce (A) overlapping exon fragments from TpLDH gene of Theileria parva: $\mathrm{M}=$ Marker, 1 = A fragment (Exon 1), 2 = B fragment (Exon 2), 3 = C fragment (Exon 3). (B) Overlapping A, B and C fragment to obtain TpLDH gene without introns: $\mathrm{M}=$ Marker, 1 and $2=T p L D H$ without intron. 


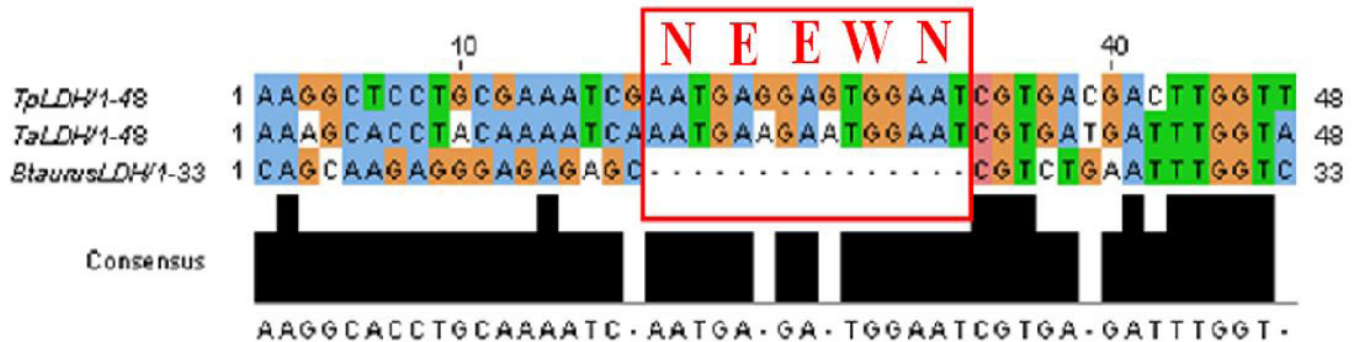

Fig.3. Multiple alignment result of lactate dehydrogenase of Theileria parva (TpLDH), T. annulata (TaLDH, NCBI Reference Sequence: XM_948495.1) and Bos taurus (BtLDH, NCBI Reference Sequence: NM_174099.2) = Penta peptide insertion is shown in red frame.
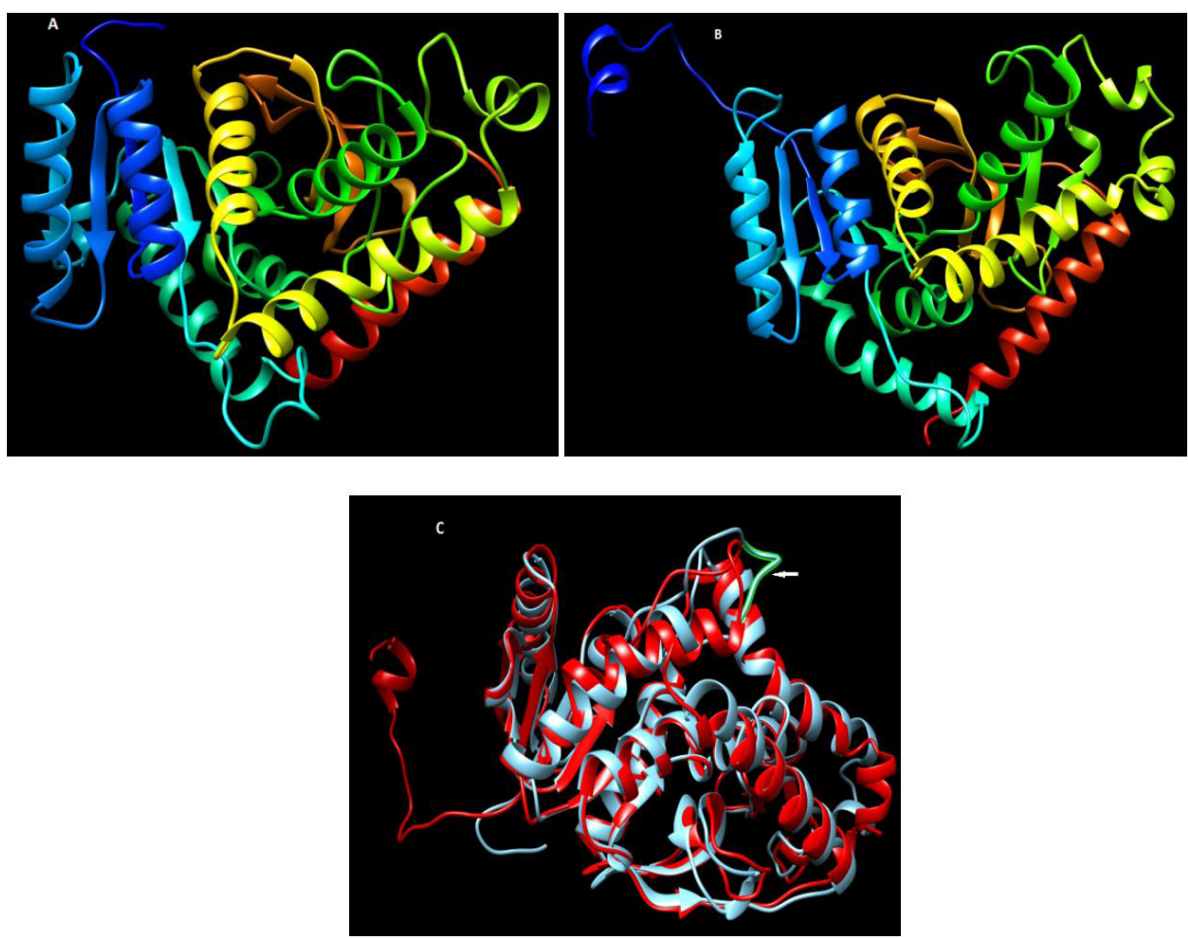

Fig.4. (A) 3D structure of TpLDH and (B) BtLDH in ribbon style. (C) Superposition of the predicted structure TpLDH with BtLDH; five amino acid insertion in the substrate specificity loop of TpLDH (arrow).

\section{DISCUSSION}

By overcoming the isolation problem of Theileria parva (Goddeeris et al. 1991) and consequently after the completion of the genome project (Gardner et al. 2005), significant data were obtained about the metabolism of this parasite. While the parasite encodes all the enzymes required for the glycolysis and tricarboxylic acid (TCA) cycle (Gardner et al. 2005), the data obtained suggest that TCA cycle in T. parva is not a conventional one (Lau 2009). The same is true for Plasmodium (Foth et al. 2005, Ralph 2005) and other apicomplexan (Lau 2009, Pino et al. 2007). This raises a fundamental question regarding the functionality of TCA cycle in T. parva (Gardner et al. 2005). It is assumed that glycolysis is the sole pathway for energy generation in T. parva and plays a formidable role in its life cycle. Thus, targeting the enzymes of this pathway (Loo et al. 2010, Schaap et al. 2004) as well as lactate dehydrogenase as anti-theilerials may prove advantageous.
The crystal structure of Plasmodium falciparum LDH (PfLDH) reveals its unusual properties. Compared to its mammalian counterparts it has a significant shift in the position of the NADH cofactor (Dunn et al. 1996). PfLDH has also unique structural differences in comparison to host LDHs. The antigenic loop (residues 205-221) in PfLDH adopts a different conformation from vertebrate LDHs (Dunn et al. 1996). It is assumed that this loop is responsible for the antigenic discrimination. Moreover, the substrate specificity loop (residues 97-112) has a penta peptide insertion (Bzik et al. 1993) that forms a separate cavity in the surface adjacent to the catalytic region which is absent in mammalian LDHs (Dunn et al. 1996). These structural differences could be exploited for selective targeting of the parasite enzyme (Alam et al. 2014). Based on the previous investigations of Plasmodium species (Cameron et al. 2004, Dunn et al. 1996), we aimed to inquire the possibility of designing new anti-theilerial drugs from the data on TpLDH in this study. To our knowledge, this is 
the first study to clone and characterize TpLDH in terms of its potential as a new drug target against East Coast Fever. The structural analysis showed that compared to the host enzyme, the LDH of T. parva had a profound difference in the substrate binding site, where a penta peptide is present. This five amino acid insertion, which is absent from host enzyme, may provide an effective drug target. With varying sequences, other apicomplexan were also shown to have such penta peptides on the active region (Dunn et al. 1996, Kavanagh et al. 2004, Schaap et al. 2004) which constitutes an adsorption region for inhibitors (Dunn et al. 1996). In a study conducted by Erdemir et al., it has also shown that there is same penta peptide insertion in lactate dehydrogenase of Theileria annulata (Erdemir et al. 2012). In line with these, $T p \mathrm{LDH}$ enzyme could be utilized as a specific target for inhibitors without harming the vertebrate host.

\section{CONCLUSIONS}

This study appears to be the first to report the isolation, removal of introns through directed mutagenesis, and cloning of $T p \mathrm{LDH}$ and showing that amino acid insertions or deletions.

As an important finding, a penta-peptide (Asn-91A, Glu-91B, Glu-91C, Trp-91D, Asn-91E) between Ser-91 ve Arg-92 of the enzyme was defined in TpLDH through comparing to the homology model of $T p \mathrm{LDH}$ and its counterpart host BtLDH.

It was determined that the insertion region, which is present on $T p \mathrm{LDH}$, do not exist in host BtLDH. Hence, this insertion site can be used as the binding sites for specific enzyme inhibitors to be developed.

Acknowledgements.- We thank Venhar Celik for her contribution to this study. We also thank Dr. Roger Pelle (International Livestock Research Institute, Nairobi, Kenya) for providing us the genomic DNA of the Theileria parva. This study has been supported by Firat University Scientific Research Projects Unit (FUBAP) with FF.11.16 project number.

\section{REFERENCES}

Alam A., Neyaz M.K. \& Ikramul Hasan S. 2014. Exploiting unique structural and functional properties of malarial glycolytic enzymes for antimalarial drug development. Malar Res. Treat 2014:451065. http://dx.doi. org/10.1155/2014/451065. PMid:25580350.

Benavides E., Rodriguez J.L. \& Romero A. 2000. Isolation and partial characterization of the Montecitos strain of Boophilus microplus (Canestrini, 1877) multiresistant to different acaricides. Ann. N.Y. Acad. Sci. 916(1):668-671. http://dx.doi.org/10.1111/j.1749-6632.2000.tb05358.x. PMid:11193697.

Bzik D.J., Fox B.A. \& Gonyer K. 1993. Expression of Plasmodium falciparum lactate dehydrogenase in Escherichia coli. Mol. Biochem. Parasitol. 59(1):155166. http://dx.doi.org/10.1016/0166-6851(93)90016-Q. PMid:8515777.

Cameron A., Read J., Tranter R., Winter V.J., Sessions R.B., Brady R.L., Vivas L., Easton A., Kendrick H., Croft S.L., Barros D., Lavandera J.L., Martin J.J., Risco F., García-Ochoa S., Gamo F.J., Sanz L., Leon L., Ruiz J.R., Gabarró R., Mallo A. \& Gomez de las Heras F. 2004. Identification and activity of a series of azole-based compounds with lactate dehydrogenase-directed anti-malarial activity. J. Biol. Chem. 279(30):31429-31439. http://dx.doi. org/10.1074/jbc.M402433200. PMid:15117937.

Chenna R., Sugawara H., Koike T., Lopez R., Gibson T.J., Higgins D.G. \& Thompson J.D. 2003. Multiple sequence alignment with the Clustal series of programs. Nucleic Acids Res. 31(13):3497-3500. http://dx.doi.org/10.1093/nar/ gkg500. PMid:12824352.
Dolan T.T., Injairu R., Gisemba F., Maina J.N., Mbadi G., Mbwiria S.K., Mulela G.H.M. \& Othieno D.A.O. 1992. A clinical Trial of Buparvaquone in the treatment of East-Coast Fever. Vet. Rec. 130(24):536-538. http://dx.doi. org/10.1136/vr.130.24.536. PMid:1441098.

Dunn C.R., Banfield M.J., Barker J.J., Higham C.W., Moreton K.M., Turgut-Balik D., Brady R.L. \& Holbrook J.J. 1996. The structure of lactate dehydrogenase from Plasmodium falciparum reveals a new target for anti-malarial design. Nature Structural Biology 3(11):912-915. http://dx.doi.org/10.1038/ nsb1196-912. PMid:8901865.

Elisa M., Hasan S.D., Moses N., Elpidius R., Skilton R. \& Gwakisa P. 2015. Genetic and antigenic diversity of Theileria parva in cattle in Eastern and Southern zones of Tanzania: a study to support control of East Coast fever. Parasitology 142(5):698-705. http://dx.doi.org/10.1017/ S0031182014001784. PMid:25417727.

Erdemir A., Aktas M., Dumanli N. \& Turgut-Balik D. 2012. Isolation, cloning and sequence analysis of lactate dehydrogenase gene from Theileria annulata may lead to design of new antitheilerial drugs. Veterinarni Medicina 57(10):559-567. http://dx.doi.org/10.17221/6368-VETMED.

Foth B.J., Stimmler L.M., Handman E., Crabb B.S., Hodder A.N. \& McFadden G.I. 2005. The malaria parasite Plasmodium falciparum has only one pyruvate dehydrogenase complex, which is located in the apicoplast. Mol. Microbiol. 55(1):39-53. http://dx.doi.org/10.1111/j.1365-2958.2004.04407.x. PMid:15612915.

Gardner M.J., Bishop R., Shah T., De Villiers E.P., Carlton J.M., Hall N., Ren Q.H., Paulsen I.T., Pain A., Berriman M., Wilson R.J.M., Sato S., Ralph S.A., Mann D.J., Xiong Z.K., Shallom S.J., Weidman J., Jiang L.X., Lynn J., Weaver B., Shoaibi A., Domingo A.R., Wasawo D., Crabtree J., Wortman J.R., Haas B., Angiuoli S.V., Creasy T.H., Lu C., Suh B., Silva J.C., Utterback T.R., Feldblyum T.V., Pertea M., Allen J., Nierman W.C., Taracha E.L.N., Salzberg S.L., White O.R., Fitzhugh H.A., Morzaria S., Venter J.C., Fraser C.M. \& Nene V. 2005. Genome sequence of Theileria parva, a bovine pathogen that transforms lymphocytes. Science 309(5731):134-137. http://dx.doi.org/10.1126/ science.1110439. PMid:15994558.

Goddeeris B.M., Dunlap S., Innes E.A. \& McKeever D.J. 1991. A simple and efficient method for purifying and quantifying schizonts from Theileria parvainfected cells. Parasitol. Res. 77(6):482-484. http://dx.doi.org/10.1007/ BF00928414. PMid:1924254.

Guo A.Y., Zhu Q.H., Chen X. \& Luo J.C. 2007. GSDS: a gene structure display server. Yi Chuan 29(8):1023-1026. http://dx.doi.org/10.1360/yc-0071023. PMid:17681935.

Horton R.M., Cai Z.L., Ho S.N. \& Pease L.R. 2013. Gene splicing by overlap extension: tailor-made genes using the polymerase chain reaction. Biotechniques 54(3):129-133. http://dx.doi.org/10.2144/000114017. PMid:23599925.

Hung S.S. \& Parkinson J. 2011. Post-genomics resources and tools for studying apicomplexan metabolism. Trends in Parasitology 27(3):131-140. http:// dx.doi.org/10.1016/j.pt.2010.11.003. PMid:21145790.

Kavanagh K.L., Elling R.A. \& Wilson D.K. 2004. Structure of Toxoplasma gondii LDH1: active-site differences from human lactate dehydrogenases and the structural basis for efficient APAD(+) use. Biochemistry 43(4):879-889. http://dx.doi.org/10.1021/bi035108g. PMid:14744130.

Kelley L.A., Mezulis S., Yates C.M., Wass M.N. \& Sternberg M.J. 2015. The Phyre2 web portal for protein modeling, prediction and analysis. Nat. Protoc. 10(6):845-858. http://dx.doi.org/10.1038/nprot.2015.053. PMid:25950237.

Kiama T.N., Kiaira J.K., Konji V.N. \& Musoke A.J. 1999. Enzymes of glucose and glycerol catabolism in in vitro-propagated Theileria parva schizonts. Vet. J. 158(3):221-227.http://dx.doi.org/10.1053/tvjl.1999.0380. PMid:10558843.

Lau A.0.T. 2009. An overview of the Babesia, Plasmodium and Theileria genomes: A comparative perspective. Mol. Biochem. Parasitol. 164(1):1-8. http://dx.doi.org/10.1016/j.molbiopara.2008.11.013. PMid:19110007. 
Loo S.S., Blake D.P., Mohd-Adnan A., Mohamed R. \& Wan K.L. 2010. Eimeria tenella glucose-6-phosphate isomerase: molecular characterization and assessment as a target for anti-coccidial control. Parasitology 137(8):11691177. http://dx.doi.org/10.1017/S0031182010000119. PMid:20233491.

Marsolier J., Perichon M., DeBarry J.D., Villoutreix B.O., Chluba J., Lopez T., Garrido C., Zhou X.Z., Lu K.P., Fritsch L., Ait-Si-Ali S., Mhadhbi M., Medjkane S. \& Weitzman J.B. 2015. Theileria parasites secrete a prolyl isomerase to maintain host leukocyte transformation. Nature 520(7547):378-382. http://dx.doi.org/10.1038/nature14044. PMid:25624101.

McHardy N., Wekesa L.S., Hudson A.T. \& Randall A.W. 1985. Antitheilerial activity of Bw720c (Buparvaquone): a comparison with Parvaquone. Res. Vet. Sci. 39(1):29-33. PMid:3929346.

Mhadhbi M., Chaouch M., Ajroud K., Darghouth M.A. \& BenAbderrazak S. 2015. Sequence polymorphism of cytochrome $b$ gene in Theileria annulata Tunisian isolates and its association with Buparvaquone treatment failure. PLoS One 10(6):e0129678. http://dx.doi.org/10.1371/journal. pone.0129678. PMid:26061414.

Mhadhbi M., Naouach A., Boumiza A., Chaabani M.F., BenAbderazzak S. \& Darghouth M.A. 2010. In vivo evidence for the resistance of Theileria annulata to buparvaquone. Vet. Parasitol. 169(3-4):241-247. http://dx.doi. org/10.1016/j.vetpar.2010.01.013. PMid:20185242.

Miller R.J., Davey R.B. \& George J.E. 2002. Modification of the food and agriculture organization larval packet test to measure amitraz-susceptibility against ixodidae. J. Med.Entomol. 39(4):645-651. http://dx.doi.org/10.1603/00222585-39.4.645. PMid:12144297.

Morrison W.I. 2009. Progress towards understanding the immunobiology of Theileria parasites. Parasitology 136(12):1415-1426. http://dx.doi. org/10.1017/S0031182009990916. PMid:19691866.

Mukhebi A.W., Perry B.D. \& Kruska R. 1992. Estimated economics of Theileriosis control in Africa. Prevent. Vet. Med. 12(1/2):73-85. http:// dx.doi.org/10.1016/0167-5877(92)90070-V.

Nural B., Erdemir A., Mutlu O., Yakarsonmez S., Danis O., Topuzogullari M. \& Turgut-Balik D. 2016. Biochemical and in silico characterization of recombinant L-lactate dehydrogenase of Theileria annulata. Mol. Biotechnol. 58(4):256267. http://dx.doi.org/10.1007/s12033-016-9924-3. PMid:26921192.

Osman S.A. \& Al-Gaabary M.H. 2007. Clinical, haematological and therapeutic studies on tropical theileriosis in water buffaloes (Bubalus bubalis) in
Egypt. Vet. Parasitol. 146(3-4):337-340. http://dx.doi.org/10.1016/j. vetpar.2007.03.012. PMid:17420101.

Pino P., Foth B.J., Kwok L.Y., Sheiner L., Schepers R., Soldati T. \& Soldati-Favre D. 2007. Dual targeting of antioxidant and metabolic enzymes to the mitochondrion and the apicoplast of Toxoplasma gondii. Plos Pathogens 3(8):e115. http://dx.doi.org/10.1371/journal.ppat.0030115. PMid:17784785.

Ralph S.A. 2005. Strange organelles, Plasmodium mitochondria lack a pyruvate dehydrogenase complex. Mol. Microbiol. 55(1):1-4. http://dx.doi. org/10.1111/j.1365-2958.2004.04314.x. PMid:15612911.

Sambrook J. \& Russell D.W. 2006. The Condensed Protocols from Molecular Cloning: a Laboratory Manual. Cold Spring Harbor Laboratory Press, Cold Spring Harbor, NY.

Schaap D., Arts G., Kroeze J., Niessen R., Roosmalen-Vos S.V., Spreeuwenberg K., Kuiper C.M., Beek-Verhoeven N.V., Kok J.J., Knegtel R.M. \& Vermeulen A.N. 2004. An Eimeria vaccine candidate appears to be lactate dehydrogenase; characterization and comparative analysis. Parasitology 128(6):603-616. http://dx.doi.org/10.1017/S0031182004005104. PMid:15206462.

Sharifiyazdi H., Namazi F., Oryan A., Shahriari R. \& Razavi M. 2012. Point mutations in the Theileria annulata cytochrome b gene is associated with buparvaquone treatment failure. Vet. Parasitol. 187(3-4):431-435. http:// dx.doi.org/10.1016/j.vetpar.2012.01.016. PMid:22305656.

Shaw M.K. 1997. The same but different: the biology of Theileria sporozoite entry into bovine cells. Int. J. Parasitol. 27(5):457-474. http://dx.doi. org/10.1016/S0020-7519(97)00015-5. PMid:9193940.

Sherman I.W. 1979. Biochemistry of Plasmodium (malarial parasites). Microbiol. Rev. 43(4):453-495. PMid:94424.

Singh D.K., Thakur M., Raghav P.R. \& Varshney B.C. 1993. Chemotherapeutic trials with four drugs in crossbred calves experimentally infected with Theileria annulata. Res. Vet. Sci. 54(1):68-71. http://dx.doi.org/10.1016/00345288(93)90013-6. PMid:8434151.

Walker A.R. 2007. Theileriosis and the tick control conundrum: a better way forward? Vet. J. 173(2):248-249. http://dx.doi.org/10.1016/j. tvjl.2005.08.024. PMid:17174580.

Yamada S., Ito Y., Imamura S., Konnai S., Ito T., Onuma M. \& Ohashi K. 2008. Rhipicephalus appendiculatus: characterization of a testis-associated protein. Exp. Parasitol. 120(4):337-342. http://dx.doi.org/10.1016/j. exppara.2008.08.010. PMid:18796305. 